\title{
Population Fluctuation of Meloidogyne incognita Infecting Cucumber in Poly-house
}

\author{
S. S. Bhati* and B. L. Baheti \\ Department of Nematology, Rajasthan College of Agriculture, Maharana Pratap University of \\ Agriculture and Technology-Udaipur, India \\ *Corresponding author
}

\section{A B S T R A C T}

\begin{tabular}{|l|}
\hline K e y w o r d s \\
$\begin{array}{l}\text { Population } \\
\text { Fluctuation, Root- } \\
\text { knot nematode, } \\
\text { Cucumber, Poly- } \\
\text { house }\end{array}$ \\
\hline Article Info \\
\hline $\begin{array}{l}\text { Accepted: } \\
\text { 26 July 2020 } \\
\text { Available Online: } \\
\text { 10 August 2020 }\end{array}$ \\
\hline
\end{tabular}

\begin{abstract}
Population fluctuations of root-knot nematode, Meloidogyne incognita during crop season were studied on cucumber in two poly-houses of different locations. For the observations plant and soil samples were taken at fifteen days intervals throughout the crop season up to 120 days. Results showed that lowest 2.60 and highest 74.00 galls $/ 5 \mathrm{~g}$ roots of cucumber found at 15 and 120 days after sowing. No egg masses observed just 15 days after sowing of crops due to root-knot nematode complete their entire life cycle within 25 to 30 days. While, maximum $63.70 \mathrm{egg}$ masses $/ 5 \mathrm{~g}$ roots produced 120 days after sowing. The maximum 317.40 and minimum 264.20 eggs and larvae per egg mass was observed at 30 and 120 days after sowing in cucumber It was observed that egg mass contain found maximum when the population level is lowest and the egg mass contained reduced with increasing in the population of root-knot nematodes. Results also showed that minimum 1347.90 and maximum 2256.90 juveniles per $100 \mathrm{cc}$ soil was found at 15 and 120 days after sowing of cucumber in poly-house.
\end{abstract}

\section{Introduction}

The cucumber (Cucumis sativus) is a climbing plant, originated in India. It is well grown throughout the world. The cucumber fruit is eaten raw or is served as a salad or cooked as a vegetable. Cucumber is an excellent source of minerals and vitamins. Mostly cucumbers grown in poly-houses are parthenocarpy and they are high yielding. The crop production under protected cultivation represents the best option to increase the production of cucumber, by promoting controlled environmental conditions for the better growth and development of the plants than the one that occurs in the open field (Smitha and Sunil, 2016). Cucumber grow in a controlled environment, which promotes a lower incidence of pests and diseases, facilitates the harvest and allows the use of higher densities of population to obtain high yields of fruits with better quality (Olalde et al., 2014).

The impact of abiotic and biotic stresses under the present changing climate decreased 
the crop production and quality. The most constraints in cucumber production in North Indian condition are the extremes of temperature, sunlight, wind velocity, unavailability of quality water, relative humidity, weeds, carbon dioxide concentration and diseases and insect pest incidence including plant parasitic nematodes. Protected cultivation means to grow with improved quality out of season under protected structures, thereby increasing the profitability for the farmer especially in adverse climatic conditions. This technology has a potential to supply of high quality vegetables in the peri-urban areas.

The crop of such an economic importance is suffered from several biotic and abiotic factors. Among biotic factors, insect pests and diseases are the most important ones including plant parasitic nematodes. Plant parasitic nematodes viz., Meloidogyne spp., Pratylenchus spp., Rotylenchulus reniformis, Tylenchorhynchus spp., Hoplolaimus spp., Helicotylenchus spp. and Xiphinema spp. have been found in poly-houses (Chandel et al., 2010; Sharma, 2010; Manju and Subramanian, 2015; Singh et al., 2015). Among nematodes, root-knot nematode (Meloidogyne spp.) is considered as most important pest of cucumber under protected cultivation. Root-knot nematode cause great losses in different crops (Bhatti and Jain, 1977; Sharma and Baheti, 1992; Baheti and Bhati, 2017).

The degree of damage depends on the pathogenic potential of population growth of nematodes which are greatly influenced by the population densities. Generally humidity and temperature reported to affect the nematode population in a particular crop. The fluctuation in nematode population was depends on major divergences in temperature and moisture (Norton, 1978). Poornima and Sivagami (1998) studied the population fluctuation of phyto-nematodes in turmeric and recorded that the population of $M$. incognita increased with increase in age of the crop and diminished as the age of the crop advances. A study on population dynamics of root knot nematode (Meloidogyne spp.) in cardamom revealed the occurrence of high number of second stage juveniles during MarApr. Crop phenology appears to be the major factor in the fluctuation of nematode population than ecological factors like rainfall and soil temperature (Eapen, 1993). Information's were available on nematodes population and their fluctuations in different crops and soils. Nowadays protected cultivation is gaining importance in quality production. However, this work has been carried out on the status of nematode population fluctuation in poly-houses and it will be helpful for calculate the timing of applications of nematode management measures.

\section{Materials and Methods}

\section{Collection of samples}

The soil and root samples of cucumber were collected from poly-house, during crop season at fifteen days interval up to 120 days. Soil and root samples were collected from rhizosphere in poly-house and brought to the laboratory and kept in refrigerator till processing. Observations on initial nematode population/100 cc soil, no. of galls $/ 5 \mathrm{~g}$ roots, no. of egg masses/5 g roots, no. of eggs and larvae/egg mass and no. of larvae/100 cc soil were recorded.

\section{Identification of root-knot nematode species}

Root samples were brought to the laboratory and washed carefully in running tap water to remove adhering soil particles. Egg masses with females were detached from roots with 
the help of teasing needle and forcep under stereoscopic binocular microscope. Egg masses were kept in water for 24 hours for hatching and females were picked up for identification of species. Perineal patterns of these females were cut with the help of scaples and the body contents were removed gently with camel brush No. 1 (Taylor and Netscher, 1974). Observation of such several patterns was recorded and the nematode species was identified as $M$. incognita (Eisenback et al., 1981).

\section{Counting of galls and egg masses}

After harvesting, root samples were collected from each experiment, labelled properly and brought to the laboratory. Roots were gently washed in running tap water to remove adhering soil particles. Well cleaned roots were cut into small pieces and $5 \mathrm{~g}$ samples were taken and observed thoroughly under microscope for counting of galls and egg masses.

\section{Counting of eggs and larvae per egg mass}

Roots were stained with $0.1 \%$ acid fuchsin lactophenol solution, rinsed in water to remove excess amount of stain and kept in clear lactophenol at least for 24 hours before examination (McBeth et al., 1941). Egg masses were randomly selected and detached from stained roots and put in a drop of clear lactophenol on glass slide, covered with cover slip and press gently so that contents of egg mass spread thoroughly. Thereafter, eggs and larvae were counted under stereoscopic binocular microscope.

\section{Estimation of initial and final nematode population}

For estimation of initial nematode population, soil samples collected from the polyhouse were brought to the laboratory and thoroughly mixed by using coring and quartering method, $100 \mathrm{cc}$ soil was taken and processed by using Cobb's sieving and decanting technique (Cobb, 1918) followed by Baermann's funnel technique (Christie and Perry, 1951). After 24 hours, the nematode suspension was drawn from the funnel in a beaker and kept for some time as such to allow the nematodes to settle down at the bottom. $100 \mathrm{ml}$ suspensions was maintained with the help of measuring cylinder and $2 \mathrm{ml}$ suspension was drawn with the help of a pipette after thoroughly bubbling and poured over a counting disc. Population was counted under stereoscopic binocular microscope.

\section{Results and Discussion}

The root-knot nematode species, Meloidogyne incognita were studied with regard to their population fluctuations on cucumber, growing under protected cultivation at two different locations. The findings of results are described and discussed below.

\section{Number of galls per $5 \mathrm{~g}$ roots}

In the crop season results showed that minimum 2.60 galls $/ 5 \mathrm{~g}$ roots of cucumber found just 15 days after sowing of cucumber during 2016 and 2017. The highest 74.00 galls $/ 5 \mathrm{~g}$ roots of cucumber found 120 days after sowing of cucumber during both years. It was happened due to exposure of root-knot nematode population with the increasing in time of well-established crop. When the rootknot nematode population increased with the time, the penetration of juveniles increased and the number of galls also increased.

\section{Number of egg masses per $5 \mathrm{~g}$ roots}

On the basis of table no. 1 results revealed that no egg masses observed just 15 days after sowing of crops due to root-knot nematode complete their entire life cycle within 25 to 30 
days. Therefore, minimum 3.90 egg masses/5 $\mathrm{g}$ roots found 30 days after sowing of cucumbers under protected cultivation in 2016 and 2017. It was also observed that maximum 63.70 egg masses/5 g roots produced 120 days after sowing in both years on cucumber under protected cultivation.

\section{Number of eggs and larvae per egg mass}

In the experimental results, it was recorded that no egg masses found 15 days after sowing of cucumber. The maximum 317.40 eggs and larvae per egg mass were observed at 30 days after sowing of cucumber under protected cultivation in 2016 and 2017. The minimum 264.20 eggs and larvae per egg mass in cucumber at 120 days after sowing of crop was recorded in 2016 and 2017. It was observed that the egg masses contain, number of eggs and larvae found maximum when the population level is lowest and the eggs contain reduced with increasing in the population of root-knot nematodes.

\section{Final nematode population per 100 cc soil}

Results showed that final nematode population was found maximum 2256.90 per $100 \mathrm{cc}$ soil in cucumber crop during 2016 and 2017 under protected cultivation at 120 days after sowing. It was also obtained that the minimum 1347.90 juveniles per $100 \mathrm{cc}$ soil found at 15 days after sowing of cucumber in poly-houses during both years.

The results of this experiment were similar to Vincx (1989), Lucas (1992), Eapen (1993) and Cerevkova et al., (2010). Vincx (1989) find out the seasonal fluctuations of the nematode community, based on the monthly samples. The mean density of the total 32 species were found between $55 \mathrm{IJs} / 10 \mathrm{~cm} 2$ (Feb. 1983) and $5610 \mathrm{IJs} / 10 \mathrm{~cm} 2$ (Jun. 1985.) and increase in reproductive activity appeared in spring and autumn. Lucas (1992) reported that population of root-knot nematodes, Meloidogyne incognita, M. arenaria and $M$. hapla fluctuated little in soil, but there was a trend toward reduced numbers at the end of the study, with higher numbers in winter than in summer in kiwi orchard, its similar trends found in both the years. Eapen (1993) found that ecological factors like rainfall and soil temperature mostly influencing the fluctuations in population of Meloidogyne spp. in a cardamom field for three years. Number of $J_{2}$ in soil was highest during March-April. Nematode population in roots increased rapidly during the post monsoon period, declined gradually during summer and was lowest in monsoon months.

A study on the seasonal fluctuation of nematode population was conducted from 2005 to 2007 at different soil depth in a hop garden and found that seasonal fluctuation of the nematode population was related to temperature and rainfall. At $20 \mathrm{~cm}$ soil depth of each year, the largest nematode population was recorded in July and the smallest from July to October.

At $40 \mathrm{~cm}$ soil depth, a decrease of nematode flow was observed from May to October (Cerevkova et al., 2010). Ghonaimy et al., (2015) also conducted an experiment based on two cropping sequences and found that the population density of root-knot nematode fluctuated with respective plants in both two sequences after 2 and 4 months from planting each crop. Cucumber and common bean in the first sequence were found to be best hosts for root knot nematode. The least number of nematodes were found on sesame. No galls or egg masses were found on onion.

Surega and Ramakrishanan (2017) conducted experiment on turmeric to find out the effect of seasonal changes on the population of plant parasitic nematodes and monitored at monthly intervals (Fig. 1). 
Table.1 Population fluctuation of root-knot nematode, $M$. incognita on cucumber in poly-house

\begin{tabular}{|c|c|c|c|c|c|c|c|c|c|c|c|c|}
\hline \multirow{2}{*}{$\begin{array}{l}\text { Days after } \\
\text { Sowing }\end{array}$} & \multicolumn{3}{|c|}{ No. of galls $/ 5 \mathrm{~g}$ roots } & \multicolumn{3}{|c|}{ No. of egg masses/5 g roots } & \multicolumn{3}{|c|}{ No. of eggs and larvae/egg mass } & \multicolumn{3}{|c|}{ No. of larvae/100 ce soil } \\
\hline & 2016 & 2017 & Pooled & 2016 & 2017 & Pooled & 2016 & 2017 & Pooled & 2016 & 2017 & Pooled \\
\hline 15 & 2.20 & 3.00 & 2.60 & 0.00 & 0.00 & 0.00 & 0.00 & 0.00 & 0.00 & 1350.60 & 1345.20 & 1347.90 \\
\hline 30 & 5.00 & 7.20 & 6.10 & 3.20 & 4.60 & 3.90 & 313.60 & 321.20 & 317.40 & 1540.20 & 1556.60 & 1548.40 \\
\hline 45 & 19.60 & 22.80 & 21.20 & 14.40 & 16.40 & 15.40 & 304.20 & 307.80 & 306.00 & 1667.80 & 1672.40 & 1670.10 \\
\hline 60 & 26.40 & 28.60 & 27.50 & 21.80 & 22.40 & 21.10 & 282.80 & 285.60 & 284.20 & 1720.20 & 1734.40 & 1727.30 \\
\hline 75 & 38.80 & 41.20 & 40.00 & 30.40 & 33.20 & 31.80 & 277.20 & 278.40 & 277.80 & 1885.40 & 1876.80 & 1881.10 \\
\hline 90 & 44.20 & 48.40 & 46.30 & 37.60 & 39.60 & 38.60 & 270.60 & 274.20 & 272.40 & 1956.60 & 1965.20 & 1960.90 \\
\hline 105 & 58.40 & 59.60 & 59.00 & 45.20 & 48.40 & 46.80 & 267.80 & 270.40 & 269.10 & 2032.80 & 2043.40 & 2038.10 \\
\hline 120 & 72.80 & 75.20 & 74.00 & 64.80 & 62.60 & 63.70 & 262.60 & 265.80 & 264.20 & 2245.20 & 2268.60 & 2256.90 \\
\hline SEm & 1.782 & 2.041 & 1.911 & 1.297 & 1.523 & 1.410 & 13.501 & 15.560 & 14.530 & 68.502 & 67.420 & 67.961 \\
\hline CD $5 \%$ & 5.161 & 5.912 & 5.536 & 3.759 & 4.413 & 4.086 & 39.111 & 45.076 & 42.093 & 198.443 & 195.309 & 196.876 \\
\hline
\end{tabular}

Data are the average value of five replications 
Fig.1 Population fluctuation of root-knot nematode, $M$. incognita on cucumber in poly-house
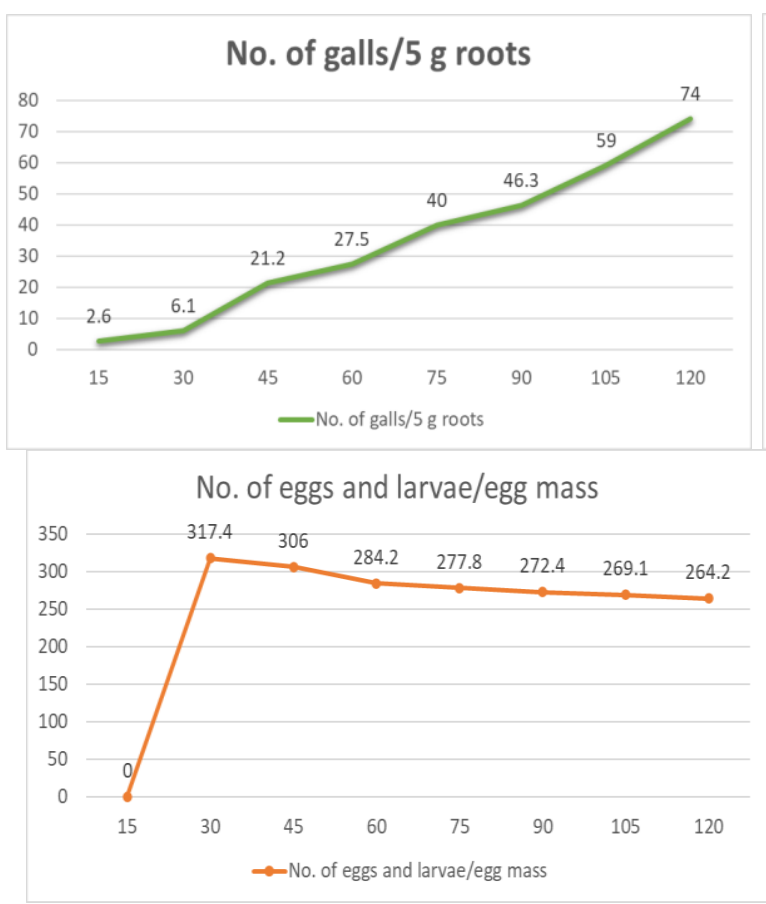

The predominant genera Meloidogyne incognita, Pratylenchus delattrei, Radopholus similis, Longidorus elongatus, Xiphinema elongatum, Hoplolaimus seinhorstii, Helicotylenchus multicinctus, Tylenchorhynchus martini and Rotylenchulus reniformis recovered from rhizosphere. Among all, root-knot nematode population gradually started to build up right from the time of planting of turmeric and reached its peak around sixth month and declined towards crop maturity. Sen (2017) carried out work in a guava orchard and reported that the maximum population of nematodes were observed during monsoon with a population of $4169 \mathrm{IJS} / 250 \mathrm{gm}$ soil in the month of July. During monsoon low soil temperature $\left(30.10^{0} \mathrm{C}-31.80^{\circ} \mathrm{C}\right)$ and high soil moisture $(20 \%-26 \%)$ in the month of July were also observed. The minimum population (204 $\mathrm{IJ} / 250 \mathrm{gm}$ soil) of soil nematodes was observed during pre and post-monsoon with a wide range of low to high soil temperature $\left(18^{\circ} \mathrm{C}-34^{0} \mathrm{C}\right)$ and low soil moisture $(10 \%$ $13 \%)$.

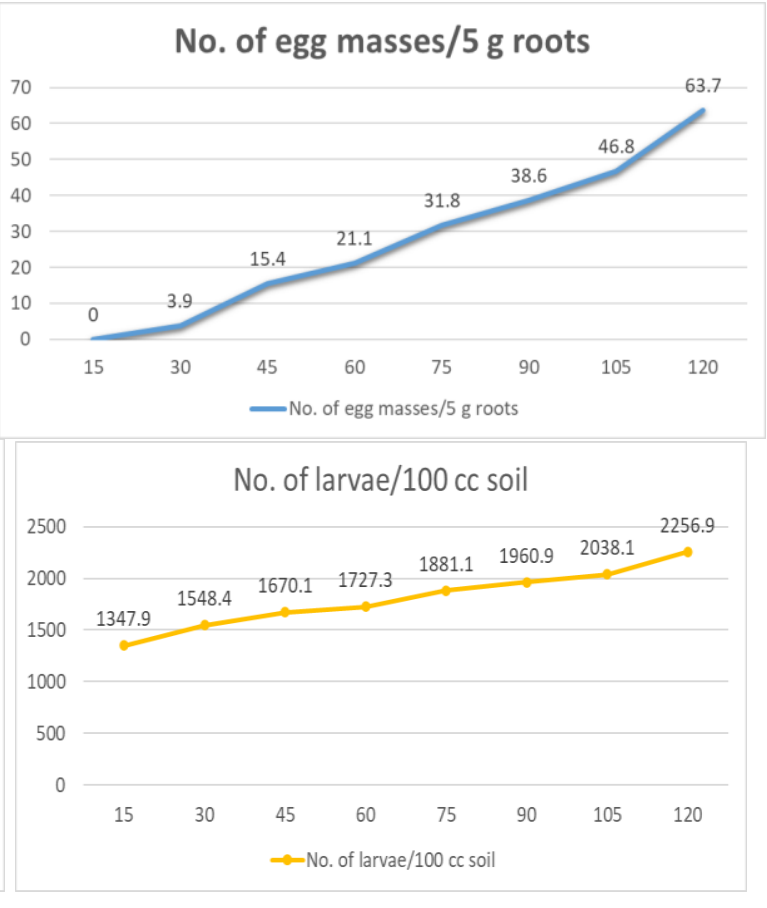

\section{Acknowledgement}

The authors are highly grateful to the Head, Department of Nematology and Dean, Rajasthan College of Agriculture, MPUAT, Udaipur (Raj) for providing necessary facilities and critically reviewed the article.

\section{References}

Baheti, B.L. and Bhati, S.S. 2017. Estimation of Losses Caused by Root-Knot Nematode, Meloidogyne incognita in Varied Soil Conditions on Okra (Abelmoschus esculentus L.). Current Nematology, 28(2): 201-207.

Bhatti, D.S. and Jain, R.K. 1977. Estimation of loss in okra, tomato and brinjal yield due to Meloidogyne incognita. Indian Journal of Nematology, 7: 37-41.

Cerevkova, A. and Cagan, L. 2012. Seasonal effects on the population dynamics of soil nematodes in a maize field. Journal of Central European Agriculture, 13(4): 739-746. 
Chandel, Y.S., Kumar, S., Jain, R.K. and Vashisth, S. 2010. An Analysis of Nematode problem in Green house Cultivation in Himachal Pradesh and Avoidable Losses Due to Meloidogyne incognita in tomato. Indian Journal of Nematology, 40(2): 198-203.

Christie, J.R. and Perry, V.G. 1951. Removing nematodes from soil. Proceeding of Helminthological Society of Washington, 18: 106-108.

Cobb, N.A. 1918. Estimating the Nematode Population of Soil. U.S. Dept. Agr. Bur. Plant. Ind. Agr. Tech. Cir. 1: 1-48.

Eapen S.J. 1993. Seasonal variations of rootknot nematode population in a cardamom plantation. Indian Journal of Nematology, 23(1): 63-68.

Eisenback, J.D., Hirschmann, H., Sasser, J.N. and Triantaphyllou, A.C. 1981. A guide to the four most common species of root-knot nematodes (Meloidogyne spp.) with a pictorial key. Crop. Publ. Deps. Plant Pathol. and Genet., North Carolina State Univ., and U.S. Agency Int. Dev. Raleigh, N.C.pp. 48.

Ghonaimy, E., Nagdi, A.M. and Youssef, M.M. 2015. Seasonal variations of population density of root knot nematode, Meloidogyne incognita as affected by different cropping sequences. Scientia Agriculturae, 10(1): 35-37.

Lucas, S.V. 1992. Seasonal population fluctuations of Meloidogyne spp. And the Pasturia penetrans group in Kiwi orchards. Plant Diseases, 78(12): 12751279.

Manju, P. and Subramanian, S. 2015. Survey of plant parasitic nematodes associated with gerbera in Tamil Nadu. International Journal of Science, 6(4): 586-589.

McBeth, C.W., Taylor, A.L. and Smith, A.L. 1941. Note on staining nematodes in root tissues. Proceeding of
Helminthological
Society
of
Washington, 8: 26.

Norton, D.C. 1978. Ecology of Plant Parasitic Nematodes. John Wiley and Sons. Inc. New York, USA, pp. 263.

Olalde, G.V.M., Mastache, L.A.A., Carreño, R.E., Martínez, S.J.Y. and Ramírez, L.M. 2014. El sistema de tutoradoy poda sobre el rendimiento de pepino. En ambiente protegido. Interciencia, 39(10):712-717.

Poornima, K. and Sivagami, V. 1999. Occurrence and seasonal population behavior of phytonematodes in turmeric (Curcuma longa L.). Pest Management in Horticultural Ecosystems, 5: 42-45.

Sen, D. 2017. Population fluctuation of soil inhabiting Nematodes in relation to soil temperature and moisture at Guava Orchard in West Bengal, India. Records of Zoological Survey of India, 117(4): 376-382.

Sharma, G.C. 2010. Status of phytophagous nematodes in poly-house grown vegetable crops in mid-hills of Himachal Pradesh. Pest management and economic zoology, 18: 122-124.

Sharma, G.L. and Baheti, B.L. 1992. Loss estimates due to root-knot nematode in peas, okra, tomato and bottle gourd crops in Rajasthan, India. Current Nematology, 3: 187-188.

Singh, K.P., Sharma, G.C., Thakur, N. and Kumari, S. 2015. Incidence of Phytoparasitic Nematodes in Vegetable Crops Grown Under Protected Cultivation in Himachal Pradesh. Indian Journal of Nematology, 45: 711.

Smitha, K. and Sunil, K.M. 2016. Influence of growing environment on growth characters of cucumber (Cucumis sativus). J. Trop. Agric., 54(2): 201203.

Surega, R. and Ramakrishanan, S. 2017. 
Comparison of nematode population and their seasonal Fluctuation in turmeric (curcuma longa L.) Under Conventional and drip irrigation methods. Global journal of Bio-science and Biotechnology, 6(3): 478-481.

Taylor, D.P. and Netscher, C. 1974. An improved technique of preparing perineal patterns of Meloidogyne spp. Nematologica, 20(2): 268-269.

Vincx, M. 1989. Seasonal fluctuations and production of nematode communities in the Belgian coastal zone of the North Sea. Verhan delingen van het symposium "invertebraten van belgie", pp. 57-66.

\section{How to cite this article:}

Bhati, S. S. and Baheti, B. L. 2020. Population Fluctuation of Meloidogyne incognita Infecting Cucumber in Poly-house. Int.J.Curr.Microbiol.App.Sci. 9(08): 3708-3715.

doi: https://doi.org/10.20546/ijcmas.2020.908.428 